University of Chitral

Journal of Botany $|\mathrm{UOCHJB}|$
ISSN: 2616-9150

2017: Vol. 01:Issue No. 01: Page No.169-183

doi: https://doi.org/10.33195/uochib-v1i1442017

https://jb.uoch.edu.pk/index.php/j1

Research Paper

Open Access

\title{
THE RESPONSE OF CAPSICUM ANNUUM L. GROWTH TO DIFFERENT PHOSPHORUS LEVEL AND SOWING DATES
}

\section{HIKMAT-UN-NISA MARWAT ${ }^{1}$, MUHAMMAD SHUAIB ${ }^{2 *}$, IKRAMULLAH KHAN ${ }^{3}$, GOHAR AYUB ${ }^{4}$, KASHIF ALI ${ }^{5}$, FIRASAT HUSSAIN ${ }^{6}$, MUHAMMAD ILYAS $^{7}$, FAROOQ JAN", FIDA HUSSAIN ${ }^{9}$}

1. Department of Weed sciences, The University of Agriculture Peshawar, Pakistan

2. School of Ecology and Environmental Science, Yunnan University, Kunming, China

3. Department of Botany, Abdul Wali Khan University Mardan, Pakistan

${ }^{4}$ Department of Horticulture, The University of Agriculture Peshawar, Pakistan

${ }^{5}$ Institute of Ecology and Geobotany, Yunnan University, No.2. North Cuihu Road, Kunming, Yunnan, P.R. China

${ }^{6}$ Department of Microbiology, University of Swabi, Pakistan

${ }^{7}$ Department of Entomology, The University of Agriculture Peshawar, Pakistan

${ }^{8}$ Department of botany, Abdulwali Khan University, Mardan, Pakistan

${ }^{9}$ Department of Botany, Qurtaba University Peshawar, Pakistan

*Corresponding Author: zeyadz44@yahoo.com

Article Published on: 23 September 2019

\begin{abstract}
s
A field research was conducted in the horticulture nursery the University of Agriculture Peshawar during the period 25 February to 14 April 2013 on the response of chilli (Capsicum annuиm) growth to phosphorus level and sowing dates, to know the suitable time of sowing for 169 University of Chitral Journl of Botany |UOCHJB|
\end{abstract}


better production of chilli, and know the optimum level of phosphorus for better growth of chilli. Amid split plot arrangements, the design used for the experiment was a randomized complete block design. Two factors involved i.e. Phosphorus levels and date of Sowing. Main plot constitutes Phosphorus levels whereas sowing date was in sub plot. Three times total 12 treatments were replicated. During this research of chilli different growth level study under phosphorous from sowing to plants ripeness and fruits. With the increase in Phosphorous level all parameters via, the height of plant, twigs no. and fruit number/plant increased significantly. Height of plant and twigs number increased significantly at its 1st blossoming and yield with an increase in $\mathrm{P}$ levels up to the cure while at final yield all parameters greatly improved up to the P2 treatment. The greatest plant tallness at final yield was obtained from P2 greatest numbers of fruits were presents in final P3 phosphorus levels. Phosphorus level (70 Kg ha-1) showed significantly best results followed by $\left(100 \mathrm{~kg} \mathrm{ha}^{-1}\right)$. The rest of the phosphorus level showed moderate results. Early sowing date ( $25^{\text {th }}$ February) was the best sowing date for bringel cultivation as compare the rest of the sowing dates. Thus it is recommended that bringel cultivation should be done during the $3^{\text {rd }}$ week of February and the phosphorus level should be between 70 and $100 \mathrm{~kg}$ ha-1 depending on the soil type

Keywords: Chilli (Capsicum annuum), Growth, Phosphorus level, sowing dates 


\section{Introduction}

Capsicum annuum is a domesticated species of the plant genus Capsicum native to southern North America and northern South America (Pickersgill, 1971; Prasad et al., 2006). This species is the most common and extensively cultivated of the five domesticated capsicums (Pickersgill 1971). The species encompasses a wide variety of shapes and sizes of peppers, both mild and hot, ranging from bell peppers to chilli peppers (Olaniyi et al., 2010). In the past, some woody forms of this species have been called $C$. frutescens, but the features that were used to distinguish those forms appear in many populations of $C$. annuum and there is no consistently recognizable $C$. frutescens species. Although the plant is not an annual and in the absence of winter frosts can survive several seasons and grow into a large perennial shrub. The single flowers are an off-white (sometimes purplish) color while the stem is densely branched and up to 60 centimeters ( 24 in) tall. The fruit is a berry and may be green, yellow or red when ripe. While the species can tolerate most climates, $C$. аппииm is especially productive in warm and dry climates (Aminifard, et al., 2012).

Chilli peppers originated in the Americas. After the Columbian Exchange, many cultivars of chilli pepper spread across the world, used in both food and medicine (Perry et al., 2007). India is the world's largest producer, consumer, and exporter of chilli peppers (Perry et al., 2007; Subbiah and Ar, 2009). Among which the city of Guntur in Andhra Pradesh produces $30 \%$ of all the chilies produced in India, and the state of Andhra Pradesh contributes to $75 \%$ of all the chilli exports from India. Chilli peppers have been a part of the human diet in the Americas since at least $7500 \mathrm{BC}$ (Subbiah and Ar, 2009). There is archaeological evidence at sites located in southwestern Ecuador that chilli peppers were domesticated more than 6000 years ago, and were one of the first self-pollinating crops cultivated in Central and South America (McLeod et al., 1983, Basu et al., 2003). Chili peppers have been a part of the human diet in the Americas since at least $7500 \mathrm{BC}$ (McLeod et al., 1983). There is archaeological evidence at sites located in southwestern Ecuador that chili peppers were domesticated more than 6000 years ago, and were one of the first self-pollinating crops cultivated in Central and South America (Basu et al., 2003). Upon its introduction into Europe, chilis were grown as botanical curiosities in the gardens of Spanish and Portuguese monasteries. But the monks experimented with the chili culinary

171 University of Chitral Journl of Botany |UOCHJB| 
potential and discovered that their pungency offered a substitute for black peppercorns, which at the time were so costly that they were used as legal currency in some countries (Eshbaugh 1975). The main objectives of the current work to know the suitable time of sowing for better production of chilli, and to know the optimum level of phosphorus for better growth of chilli

\section{Materials and Methods}

An experiment was conducted at Ornamental nursery, Department of Horticulture, The University of Agriculture Peshawar in February 2013. The design used in the experiment was a randomized complete block with split plot arrangement. There were two factors i.e. Phosphorus levels and date of sowing. Phosphorus levels were kept in the main plot while sowing date was in subplot. A total of twelve treatments were replicated thrice.

\section{Soil Preparation and Analysis}

Soil was ploughed up thoroughly and then was leveled through the cutter. Well, rotten farm yard manure was mixed with the soil. Recommended dose of Di-ammonium Phosphate (DAP) was incorporated into the soil before transplantation of seedling. Ridges will be made manually at the proper height. A space of $60 \mathrm{~cm}$ will be kept between ridges and $30 \mathrm{~cm}$, between plants. One variety of chilli (long green) and different doses of DAP will be applied to plots in accordance with the field layout.

\section{Nursery Raising and Transplantation of seedlings}

The seeds of chilli used in the experiment were taken from the market. Which were sown in pots on $25^{\text {th }}$ February. The $2^{\text {nd }}$ date of sowing was $4^{\text {th }}$ March 2013 while the $3^{\text {rd }}$ date of sowing in pots was $14^{\text {th }}$ March 2013. The seed was watered after sowing. After that, the water was applied according to the requirements. The seedling of obviously equal height and vigor was transplanted on April, $12^{\text {th }}$ 2013. The seedling was immediately irrigated. Ridges were made manually at the proper height. A space of $60 \mathrm{~cm}$ was kept between ridges and $30 \mathrm{~cm}$ between plants Tab. 1 .

\section{Factor A (Phosphorus levels, $\mathrm{kg} \mathrm{ha}^{-1}$ ) Factor B (Sowing dates)}

P0: Control

D1: February $25^{\text {th }}$

P1: $\quad 60$

D2: $\quad 4^{\text {th }}$ March

P2: $\quad 80$

D3: April 14

P3: $\quad 100$

\section{Parameters to be measured:-}

Plant height $(\mathrm{cm})$

172 University of Chitral Journl of Botany |UOCHJB| 
The data on plant height will be recorded with the help of a measuring tape by measuring the height from the soil to the top of the main stem.

\section{Number of branches plant ${ }^{-1}$}

Data will be collected by counting a total number of branches in selected plants originating from the main stem and their average was taken.

\section{Days to flowering}

Data for days to flowering will be taken by counting the days from the date of transplanting to first flowering initiation.

\section{Number of Seed per Fruit}

Five plants will be selected randomly in each plot of each replication for number of fruits and their average will be calculated.

\section{Number of fruits per plant}

Five plants will be selected randomly in each plot of each replication for a number of fruits and their average will be calculated.

\section{Yield/ Plot}

Yield/ Plot was calculated using the following formulae:

$$
\text { yield / Plot }=\frac{\text { yield } \text { plot }^{-1}(\mathrm{~kg}) \times 10000 \mathrm{~m}^{2}}{\text { plot area }\left(\mathrm{m}^{2}\right)}
$$

\section{Results and Discussion}

\section{Plant Height (cm):}

Table 2 is showing the result relates to plant height $(\mathrm{cm})$ of Capsicum Annuum sowing date and the ANOVA in Tab. 2. The sowing date \& phosphorus level and interaction had considerable influence on plant height as revealed by the analysis of the data.

The mean values of various levels of phosphorus proved that uppermost plant height $(63.778 \mathrm{~cm})$ was tabulated for plants treated with $0 \mathrm{~kg} \mathrm{ha}^{-1}$ phosphorus, followed by $(65.889 \mathrm{~cm})$ receiving 60 $\mathrm{kg} \mathrm{ha}^{-1}$ phosphorus whereas least plant height $(61.704 \mathrm{~cm})$ was recorded in treatment having 100 $\mathrm{kg} \mathrm{ha}^{-1}$ phosphorus. The interaction effects were also found significant. Highest plant height was recorded for sowing date $(57.667 \mathrm{~cm})$ treated with $0 \mathrm{~kg} \mathrm{ha}^{-1}$ phosphorus, where lowest plant height (55.667) was calculated for sowing date in control treatment. Plant tallness is a role of the 
common influence of environmental interactions, genetics build up and nutritional contents of the soil. Information concerning plant tallness was noticeably effected by cultivars and zinc doses. Plant tallness at uppermost was observed for sowing date. These changes in height of plants of different sowing dates can be because of ecological effects or genetic build up. Furthermore, the tallest plant was the one that was treated with $80 \mathrm{~kg} \mathrm{ha}^{-1}$ phosphorus while minimum plant height was observed from the phosphorus level $100 \mathrm{~kg} \mathrm{ha}^{-1}$ the possible reason may be that phosphorus takes part in chlorophyll formation which may have favored cell divisions, meristematic growth in apical tissues, enlargement of cell and synthesis of new cell wall. These consequences are in line with the discoveries of Lahbib et al., (2012). Who observed that with increasing phosphorus dose the height of plant was also increased.

\section{Days to flowering:}

The statistical analysis showed that sowing dates, phosphorus level and the interaction was significant as publicized in Table 3.However it is clear from the average value of various level of phosphorus that the plants that were applied with control treatment took more (number of days) days to flower followed by (number of days) receiving $40 \mathrm{~kg} \mathrm{ha}^{-1}$ phosphorus, while the plants supplied with $70 \mathrm{~kg} \mathrm{ha}^{-1}$ phosphorus took the least number of days to flower. Interaction effects were found significant, however, application of $60 \mathrm{~kg} \mathrm{ha}^{-1}$ phosphorus to sowing date took the highest number of days to flower (number of days) and also for sowing date at control treatment. At the same time, the minimum days to flowering (number of days) was noted for sowing date at $100 \mathrm{~kg} \mathrm{ha}^{-1}$ phosphorus level. Data regarding days to flowering was found significant for phosphorus levels and sowing date, yet flowers appear on the plant in more days and minimum.

\section{Table 1. Field lay out will be as follow}

Replication I

\begin{tabular}{l|l|l|l|}
\hline Po & D1 & D2 & D3 \\
\hline P1 & D2 & D3 & D1 \\
\hline P2 & D3 & D1 & D2 \\
\hline P3 & D1 & D2 & D3 \\
\hline Replication II & D1 & D2 \\
\hline P3 & D2 & D3 & D3 \\
\hline P0 & D3 & D1 & D1 \\
\hline P2 & D1 & D2 & D2 \\
\hline P1 & \multicolumn{1}{l|}{} \\
\hline
\end{tabular}

Replication III

174 University of Chitral Journl of Botany |UOCHJB| 


\begin{tabular}{|l|l|l|l|}
\hline P2 & D1 & D2 & D3 \\
\hline P3 & D2 & D3 & D1 \\
\hline P1 & D3 & D1 & D2 \\
\hline P0 & D1 & D2 & D3 \\
\hline
\end{tabular}

Table 2. Effect of sowing dates and different phosphorus levels effect plant height in bringel.

\begin{tabular}{|l|l|l|l|l|}
\hline \multirow{2}{*}{ Treatment } & \multicolumn{3}{|l|}{ Sowing dates } & \multicolumn{2}{l|}{ Mean } \\
\cline { 2 - 6 } & $1^{\text {st }}$ & $2^{\text {nd }}$ & $3^{\text {rd }}$ & \\
\hline 0 & $57.667 \quad \mathrm{BC}$ & $67.333 \mathrm{ABC}$ & $66.333 \mathrm{ABC}$ & $63.778 \quad \mathrm{~B}$ \\
\hline 60 & $64.667 \mathrm{ABC}$ & $71.667 \mathrm{~A}$ & $61.333 \mathrm{ABC}$ & $65.889 \mathrm{~B}$ \\
\hline 80 & $74.333 \mathrm{~A}$ & $73.333 \mathrm{~A}$ & $71.000 \mathrm{AB}$ & $72.889 \mathrm{~A}$ \\
\hline 100 & $55.667 \mathrm{C}$ & $64.667 \mathrm{ABC}$ & $64.778 \mathrm{ABC}$ & $61.704 \mathrm{~B}$ \\
\hline Mean & $63.083 \mathrm{~A}$ & $69.250 \mathrm{~A}$ & $65.861 \mathrm{~A}$ & \\
\hline
\end{tabular}

sowing dates: 2.776

LSD for phosphorus level: 2.093

Table 3. Effect of sowing dates and different phosphorus levels effect days to flowering in Chilli.

\begin{tabular}{|l|l|l|l|l|}
\hline \multirow{3}{*}{ Treatment } & \multicolumn{2}{|l|}{ Sowing dates } & \multicolumn{1}{|l|}{ Mean } \\
\cline { 2 - 5 } & $\mathbf{1}^{\text {st }}$ & 2nd & $\mathbf{3}^{\text {rd }}$ & \\
\hline $\mathbf{0}$ & 49.667 & 50.000 & 48.667 & $49.444 \quad$ B \\
\hline $\mathbf{6 0}$ & 52.333 & 55.000 & 47.333 & $51.556 \quad$ B \\
\hline $\mathbf{8 0}$ & 59.000 & 56.667 & 58.667 & $58.111 \quad$ A \\
\hline $\mathbf{1 0 0}$ & 48.333 & 53.333 & 48.222 & $49.963 \quad$ B \\
\hline
\end{tabular}

175 University of Chitral Journl of Botany |UOCHJB| 


\begin{tabular}{|l|l|l|l|l|}
\hline Mean & 52.333 A & 53.750 A & 50.722 AS & \\
\hline
\end{tabular}

LSD for sowing dates: 2.776

LSD for phosphorus level: 2.093

Table 4.Effect of sowing dates and different phosphorus levels effect days to fruiting in Chilli.

\begin{tabular}{|c|c|c|c|c|}
\hline \multirow{2}{*}{ Treatment } & \multicolumn{3}{|c|}{ Sowing dates1st } & \multirow{2}{*}{ Mean } \\
\hline & $1^{\text {st }}$ & 2nd & $3^{\text {rd }}$ & \\
\hline 0 & $\begin{array}{l}42.667 \\
\mathrm{CD}\end{array}$ & $\begin{array}{l}45.333 \\
\text { BCD }\end{array}$ & $\begin{array}{l}37.000 \\
\text { D }\end{array}$ & $41.667 \quad \mathrm{C}$ \\
\hline 60 & $\begin{array}{l}50.667 \\
\text { ABCD }\end{array}$ & $\begin{array}{l}45.000 \\
\text { BCD }\end{array}$ & $\begin{array}{l}41.333 \\
D\end{array}$ & $45.667 \mathrm{BC}$ \\
\hline 80 & $\begin{array}{l}59.000 \\
\mathrm{AB}\end{array}$ & ${ }^{6}{ }^{67.000}$ & $\begin{array}{l}63.667 \\
\mathrm{~A}\end{array}$ & $63.222 \mathrm{~A}$ \\
\hline 100 & $\begin{array}{l}46.333 \\
\text { BCD }\end{array}$ & $\begin{array}{l}47.000 \\
\text { BCD }\end{array}$ & $\begin{array}{c}57.444 \\
\text { ABC }\end{array}$ & 50.259 B \\
\hline Mean & $\mathrm{A}^{49.667}$ & ${ }^{51.083}$ & $\begin{array}{l}49.861 \\
A^{4}\end{array}$ & \\
\hline
\end{tabular}

LSD for sowing dates: 2.776

LSD for phosphorus level: 2.093 
Table 5. Effect of sowing dates and different phosphorus levels effect no of fruit in Chilli.

\begin{tabular}{|c|c|c|c|c|}
\hline \multirow{2}{*}{ Treatment } & \multicolumn{3}{|c|}{ Sowing dates } & \multirow[t]{2}{*}{ Mean } \\
\hline & $1^{\text {st }}$ & 2nd & $3^{\text {rd }}$ & \\
\hline $\mathbf{0}$ & $\mathrm{A}^{43.333}$ & $\begin{array}{l}47.333 \\
\text { A }\end{array}$ & $\begin{array}{l}4^{41.667} \\
\text { A }\end{array}$ & $44.111 \mathrm{~A}$ \\
\hline 60 & $\begin{array}{l}41.333 \\
\mathrm{~A}\end{array}$ & $\begin{array}{l}44.333 \\
\mathrm{~A}\end{array}$ & $\mathrm{~A}^{50.000}$ & $45.222 \mathrm{~A}$ \\
\hline 80 & $\mathrm{~A}^{53.000}$ & $\begin{array}{l}52.333 \\
\text { A }\end{array}$ & $\begin{array}{l}51.667 \\
\text { A }\end{array}$ & $52.333 \mathrm{~A}$ \\
\hline 100 & $\mathrm{~A}^{48.333}$ & $\begin{array}{l}45.667 \\
\text { A }\end{array}$ & $\begin{array}{l}48.556 \\
\text { A }\end{array}$ & $47.519 \mathrm{~A}$ \\
\hline Mean & $\begin{array}{l}46.500 \\
\text { A }\end{array}$ & $\begin{array}{l}47.417 \\
\text { A }\end{array}$ & ${ }^{47.972}$ & \\
\hline
\end{tabular}

LSD for sowing dates: 2.776

LSD for phosphorus level: 2.093

Table 6. Effect of sowing dates and different phosphorus levels effect of fruit weight in Chilli

\begin{tabular}{|l|c|l|l|ll|}
\hline \multirow{2}{*}{ Treatment } & \multicolumn{3}{|c|}{ Sowing dates } & \multicolumn{2}{c|}{ Mean } \\
\cline { 2 - 6 } & \multicolumn{1}{|c|}{$\mathbf{1}^{\text {st }}$} & 2nd & $\mathbf{3}^{\text {rd }}$ & & \\
\hline $\mathbf{0}$ & 5.0000 & 5.3333 & 5.6667 & 5.3333 & $\mathrm{~B}$ \\
\hline $\mathbf{6 0}$ & 6.3333 & 5.3333 & 5.3333 & 5.6667 & $\mathrm{~B}$ \\
\hline $\mathbf{8 0}$ & 7.3333 & 6.0000 & 7.0000 & 6.7778 & $\mathrm{~A}$ \\
\hline $\mathbf{1 0 0}$ & 5.6667 & 5.0000 & 5.0000 & $5.2222 \quad \mathrm{~B}$ \\
\hline Mean & 6.0833 & 5.4167 & 5.7500 & & \\
& $\mathrm{~A}$ & $\mathrm{~A}$ & $\mathrm{~A}$ & & \\
\hline
\end{tabular}

LSD for sowing dates: 2.776

LSD for phosphorus level: 2.093 


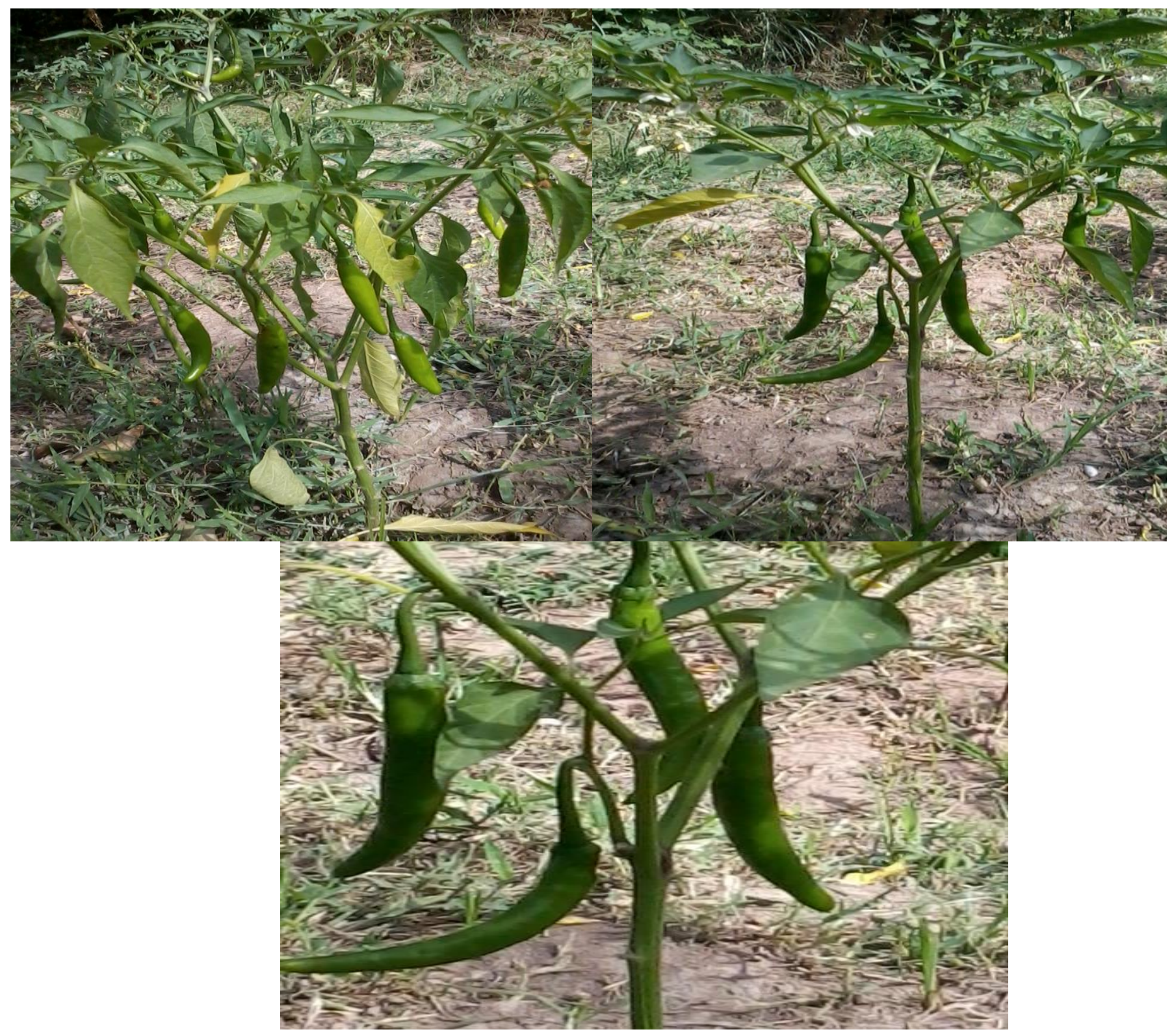

Figure 1. Represent the fruits of Chili plant with the addition of different phosphorous

days were recorded for the plant which may be credited to the varietal characteristic of this sowing date. Uppermost numbers of days to flowering were calculated with control treatment while minimum with $0 \mathrm{~kg} \mathrm{ha}^{-1}$ phosphorus level. The current results is similar to the results of Jabeen and Mirza (2004) who reported a significant effect of phosphorus on days to flowering.

178 University of Chitral Journl of Botany |UOCHJB| 


\section{Days to fruiting:}

The statistical analysis showed that sowing date, phosphorus doses and the interaction was significant as shown in Table 4. Though it is clear from the mean values of unlike doses of phosphorus that highest number of days to fruiting (50.259) was calculated for plants supplied with $100 \mathrm{~kg} \mathrm{ha}^{-1}$ phosphorus, followed by (41.667) receiving control treatment, while least number of days to fruiting was noted for plants supplied with $0 \mathrm{~kg} \mathrm{ha}^{-1}$ phosphorus. The interaction effect was found significant; however, application of $100 \mathrm{~kg} \mathrm{ha}^{-1}$ phosphorus to sowing date, took a maximum number of days to fruiting 50.259. Also, the minimum amount of days to fruiting (37.000) was recorded for sowing date at $0 \mathrm{~kg} \mathrm{ha}^{-1}$ phosphorus. Data regarding days to fruiting was found significant for phosphorus levels and cultivars. However, sowing date more days to fruiting, followed by showing date while leas days were noted for phosphorus the difference noted may be days to fruiting were observed with100 $\mathrm{kg} \mathrm{ha}^{-1}$ phosphorus while minimum with $60 \mathrm{~kg} \mathrm{ha}^{-1}$ phosphorus. The following results are not in resemblance with the conclusion of Shamima and Islam (1989) which might be because of the difference in experimental methods and environmental condition.

\section{A number of fruits per plant:}

Tab. 5 showed the data recorded on number of fruits per plan and its analysis of variance I sequence. The different phosphorus doses, sowing dates, and interaction resulted in considerable effect on a number of fruits per plant as shown by both tables. Comparing the average standards for various levels of phosphorus exposed that a maximum number of fruits per plant 41.33 was noted for $60 \mathrm{~kg} \mathrm{ha}^{-1}$ phosphorus while least number of fruits per plant 41.667 were found in control treatment. Highest numbers of fruits per plant 53.00 were noted for sowing date followed by (52.33) for March $2^{\text {nd }}$, and 47.417 were observed for sowing date. The interaction resulted in a significant effect. The sowing date $14^{\text {th }}$ March produced uppermost numbers of fruits per plant 52.33 were noted for $80 \mathrm{~kg} \mathrm{ha}^{-1}$ phosphorus while least number of fruits per plant (44.11) was found in control treatment. Data regarding fruits per plant was significantly influenced by phosphorus levels and sowing date. February $25^{\text {th }}$ resulted in a maximum number of fruits per plant, while $4 \& 14^{\text {th }}$ of March produced minimum, which may be due to the genetic makeup of 
these sowing dates. Phosphorus at $80 \mathrm{~kg} \mathrm{ha}^{-1}$ recorded maximum fruits per plant, also minimum amounts of fruits per plant were observed in control plots.

\section{Fruit weight (g):}

The data on the fruit weight of eggplant cultivars s give in table 6. The statistical analysis of the data showed that dissimilar sowing dates, phosphorus levels, and their interaction produced a considerable influence on the fruit weight. The means values of different levels of Phosphorus revealed the highest fruit weight $(6.778 \mathrm{~g})$ was observed for $80 \mathrm{~kg} \mathrm{ha}^{-1}$ and the lowest $(5.667 \mathrm{~g})$ was recorded in control treatment i.e. $60 \mathrm{~kg} \mathrm{ha}^{-1}$. The maximum fruit weight $(7.333 \mathrm{~g})$ was observed for sowing date February, $25^{\text {th }}$ followed by $6.00 \mathrm{~g}$ for March $4^{\text {th }}$ while lowest fruit weight $5.00 \mathrm{~g}$ was found for sowing date March $14^{\text {th }}$. The interaction was also found significant. The application of $80 \mathrm{~kg} \mathrm{ha}^{-1}$ phosphorus level produced the highest fruit Wight that is $7.33 \mathrm{~g}$ although smallest fruit weight is $5.00 \mathrm{~g}$ and 6.00 was counted for sowing date February $25^{\text {th }}$ and March $4^{\text {th }}$ respectively with control and $60 \mathrm{~kg} \mathrm{ha}^{-1}$ phosphorus level.

Records on fruit weight were considerably affected by sowing dates and phosphorus levels. Maximum fruit weight was noted for sowing date February, $25^{\text {th }}$ and while least amount of fruit weight was found for March, $4^{\text {th, }}$ and $14^{\text {th }}$ of March Maximum fruit weight was observed with the use of $80 \mathrm{~kg} \mathrm{ha}^{-1}$ phosphorus, yet as minimum fruit weight from control treatments.

\section{Summary}

A trial entitled "Response of chilli to Phosphorus levels and dates of sowing" was conducted at Ornamental Nursery, Department of Horticulture, The University of Agriculture Peshawar in February 2013. The experiment was laid out in randomized complete block (RCB) design with split plot arrangements. There were two factors i.e. Phosphorus levels and dates of Sowing. Phosphorus levels were assigned to the main plot while sowing dates were kept in the subplot. The data on Number of branches plant ${ }^{-1}$, Days to flowering, Days to fruiting, Number of fruits plant $^{-1}$ and Yield Plot ${ }^{-1}$ were significantly affected by phosphorus level and date of sowing. While the data on plant height was no significant. Overall results showed that early sowing date (February 25) produced significantly good results as compared to the rest of the sowing dates. Moreover, phosphorus level was also significantly affected the experimental parameters. Phosphorus level $\left(70 \mathrm{~kg} \mathrm{ha}^{-1}\right)$ produced significantly best results in all the parameters followed by Phosphorus level $\left(100 \mathrm{kgha}^{-1}\right)$ in almost all the parameters. The soil was thoroughly ploughed up and then was leveled through the cutter. Well, rotten farmyard manure was mixed with the 
soil. The recommended dose of Di-ammonium Phosphate (DAP) was incorporated into the soil before the transplantation of seedling. Ridges were made manually at the proper height. A space of $60 \mathrm{~cm}$ was kept between ridges while plant to plant space was kept $30 \mathrm{~cm}$. A variety of chilli was sown on ridges accordingly.

The seeds of Chilli cultivars used in the experiment were taken from the market, which was sown in pots on $25^{\text {th }}$ February. The $2^{\text {nd }}$ date of sowing was $4^{\text {th }}$ March 2013 while the $3^{\text {rd }}$ date of sowing in pots was $14^{\text {th }}$ March 2013 . The seed was watered after sowing. After that, the water was applied according to the requirements. The seedling of obviously equal height and vigor was transplanted on April, 12 ${ }^{\text {th }}$ 2013. The seedling was immediately irrigated. Ridges were made manually at the proper height. Results of almost all the parameters showed that early sowing of Chilli is recommended with phosphorus level $\left(70 \& 100 \mathrm{~kg} \mathrm{ha}^{-1}\right)$.

\section{Conclusions}

Phosphorus level $\left(70 \mathrm{Kg} \mathrm{ha}^{-1}\right)$ showed significantly best results followed by $\left(100 \mathrm{~kg} \mathrm{ha}^{-1}\right)$. The rest of the phosphorus level showed moderate results. Early sowing date $\left(25^{\text {th }}\right.$ February) was the best sowing date for bringel cultivation as compare the rest of the sowing dates. Thus it is recommended that bringel cultivation should be done during the $3^{\text {rd }}$ week of February and the phosphorus level should be between 70 and $100 \mathrm{~kg}$ ha- 1 depending on the soil type.

\section{References}

Ashok, P.K. and K. Upadhyaya, 2012. Tannins are astringent. J. Pharmacogn. Phytochem., 1: 4550.

Ashrafuzzaman, M., Hossain, M.M., Ismail, M.R., Haque, M.S., Shahidullah, S.M., Zaman, S.U, 2009. Regeneration potential of seedling explants of chilli Capsicum annuит. J. Agri. Biol., 6: 2.

Basu, S. K., et al. (2003). "Capsicum: historical and botanical perspectives." Capsicum: the genus Capsicum 33: 1-15.

Eshbaugh, W. H. (1975). Genetic and Biochemical Systematic Studies of Chili Peppers (Capsicum- Solanaceae).Bulletin of the Torrey Botanical Club, 102(6), 396. doi: $10.2307 / 2484766$ 
Fudholi, A., Othman, M. Y., Ruslan, M. H., \& Sopian, K. (2013). Drying of MalaysianCapsicum annuumL. (Red Chili) Dried by Open and Solar Drying. International Journal of Photoenergy, 2013, 1-9. doi:10.1155/2013/167895

Karima Lahbib,. (2012). Genetic diversity evaluation of pepper (Capsicum annuum L.) in Tunisia based on morphologic characters. AFRICAN JOURNAL OF AGRICULTURAL RESEEARCH, 7(23). doi:10.5897/ajar11.2171

Khan, M.S.I., Roy, S.S., Pall, K.K, 2010. Nitrogen and Phosphorus Efficiency on the Growth and Yield Attributes of Capsicum. Acad. J. Pl. Sci. 3 (2): 71-78.

Ludilov, V.A., Ludilova, M.I, 1977,1975. Application of high rate of mineral fertilizers in capsicums and eggplant. Nauchnye Trudy NII Ovoshch. Khva. 3:58-63. (Hort. Abst.1977,47 (1): (1975) 524).

Maheshwari. (2011). Assessment of genetic diversity among Capsicum annuum L. genotypes using RAPD markers. AFRICAN JOURNAL OF BIOTECHNOLOGY, 10(76). doi:10.5897/ajb11.497

McLeod, M. J., Guttman, S. I., Eshbaugh, W. H., \& Rayle, R. E. (1983). An Electrophoretic Study of Evolution in Capsicum (Solanaceae). Evolution, 37(3), 562. doi:10.2307/2408269

Misra, S., Lal, R. K., Darokar, M. P., \& Khanuja, S. P. (2011). Genetic Variability in Germplasm Accessions of <i>Capsicum annuum</i> L. American Journal of Plant Sciences, 02(05), 629-635. doi:10.4236/ajps.2011.25074

Mohammad Hossein Aminifard. (2012). Effect of plant density and nitrogen fertilizer on growth, yield and fruit quality of sweet pepper (Capsicum annum L.). AFRICAN JOURNAL OF AGRICULTURAL RESEEARCH, 7(6). doi:10.5897/ajar10.505

Narmin, Y.S., Jamei, R., Heidari, R, 2012. Antioxidant activities of two sweet pepper Capsicum annuит L. varieties phenolic extracts and the effects of thermal treatment. Avicenna J. Phytomedicine. 3(1): 25-34.

Nyla, J. and Mirza, B, 2004. Ethyl Methane Sulfonate Induces Morphological Mutations in (Capsicum annuum). Asian Journal of Plant Sciences, 1(4), 425-428. doi:10.3923/ajps.2002.425.428 
Olaniyi, J., et al. (2010). "The effect of organo-mineral and inorganic fertilizers on the growth, fruit yield, quality and chemical compositions of okra." Journal of Animal \& Plant Sciences 9(1): 1135-1140.

Perry, L., Dickau, R., Zarrillo, S., Holst, I., Pearsall, D. M., Piperno, D. R., ... Zeidler, J. A. (2007). Starch Fossils and the Domestication and Dispersal of Chili Peppers (Capsicum spp. L.) in the Americas. Science, 315(5814), 986-988. doi:10.1126/science.1136914

Pickersgill, B. (1971). Relationships Between Weedy and Cultivated Forms in Some Species of Chili Peppers (Genus capsicum). Evolution, 25(4), 683. doi:10.2307/2406949

Prasad, B. C., Kumar, V., Gururaj, H. B., Parimalan, R., Giridhar, P., \& Ravishankar, G. A. (2006). Characterization of capsaicin synthase and identification of its gene (csy1) for pungency factor capsaicin in pepper (Capsicum sp.). Proceedings of the National Academy of Sciences, 103(36), 13315-13320. doi:10.1073/pnas.0605805103

Shamima, N. and Islam, M.S, 1989. Response of chilli to NPK and S fertilization. Bangladesh Hort. 17(2): 5-9.

Sharfun, N., Mushtaq, M. and Pathan, I.H, 2004. Seed-borne mycoflora of Capsicum annuum imported from India. Pak. J. Bot. 36(1): 191-197.

Subbiah, A. and S. JeyAkumAr (2009). "Production and Marketing of chillies." Facts for You 29(6): 1-19. 